University of Nebraska - Lincoln

DigitalCommons@University of Nebraska - Lincoln

Publications, Agencies and Staff of the U.S.

Department of Commerce

U.S. Department of Commerce

1988

\title{
Distribution, Abundance, and Biomass of Freshwater Mussels (Bivalvia: Unionidae) in Lake St. Clair
}

Thomas F. Nalepa

National Oceanic and Atmospheric Administration, thomas.nalepa@noaa.gov

Jeffrey M. Gauvin

National Oceanic and Atmospheric Administration

Follow this and additional works at: https://digitalcommons.unl.edu/usdeptcommercepub

Part of the Environmental Sciences Commons

Nalepa, Thomas F. and Gauvin, Jeffrey M., "Distribution, Abundance, and Biomass of Freshwater Mussels (Bivalvia: Unionidae) in Lake St. Clair" (1988). Publications, Agencies and Staff of the U.S. Department of Commerce. 387.

https://digitalcommons.unl.edu/usdeptcommercepub/387

This Article is brought to you for free and open access by the U.S. Department of Commerce at DigitalCommons@University of Nebraska - Lincoln. It has been accepted for inclusion in Publications, Agencies and Staff of the U.S. Department of Commerce by an authorized administrator of DigitalCommons@University of Nebraska - Lincoln. 


\title{
DISTRIBUTION, ABUNDANCE, AND BIOMASS OF FRESHWATER MUSSELS (BIVALVIA:UNIONIDAE) IN LAKE ST. CLAIR
}

\author{
Thomas F. Nalepa and Jeffrey M. Gauvin \\ National Oceanic and Atmospheric Administration \\ Great Lakes Environmental Research Laboratory \\ 2205 Commonwealth Blvd. \\ Ann Arbor, Michigan 48105
}

\begin{abstract}
A mussel population survey was conducted in Lake St. Clair with divers using SCUBA to sample at 29 stations throughout the lake. Mean abundance was $2 \mathrm{~m}^{-2}$ and mean biomass was $4.4 \mathrm{~g}$ dry wt $\mathrm{m}^{-2}$. Of the 18 species collected, Lampsilis radiata siliquoidea was by far the most abundant, accounting for $45 \%$ of all individuals. The age-frequency distribution of $\mathrm{L}$. r. siliquoidea was dominated by individuals between 9 and 12 years old. In contrast, the second most abundant species, Leptodea fragilis, showed yearly variation in recruitment with no apparent trends in year class strength. Annual production of L. r. siliquoidea was $0.20 \mathrm{~g} \mathrm{~m}^{-2} y^{-1}$ and the turnover ratio was 0.13. The diversity and composition of mussels in Lake St. Clair appear little changed since the turn of the century, but there are indications that population numbers may be declining in the future. ADDITIONAL INDEX WORDS: Molluscs, clams, productivity.
\end{abstract}

\section{INTRODUCTION}

The species composition and distribution of unionid bivalves (mussels) in the Great Lakes are well-known (Gooderich and van der Schalie 1932, van der Schalie 1961, Mackie et. al. 1980, Clarke 1981), but accurate estimates of mussel abundance, biomass, and production are generally lacking. This can be attributed directly to the difficulty in obtaining quantitative samples of mussels, particularly in offshore waters. Conventional sampling devices such as grab samplers do not adequately sample mussel populations (Haukioja and Hakala 1974, Isom and Gooch 1986), while dredges, although used by some to quantify mussels (Wood 1963), provide uncertain abundance estimates even when calibrated. Sampling with SCUBA is undoubtedly the most accurate technique for obtaining quantitative population estimates (Isom and Gooch 1986), but studies using this approach in the Great Lakes have been either qualitative in nature (van der Schalie 1986), concerned only with growth rates (McCuaig and Green 1983), or have had a limited sampling area (McCall et. al. 1979, University of Windsor 1984).

In this paper we give the composition, abundance, and biomass of the mussel population in Lake St. Clair and determine the production and age structure of the most abundant species, Lampsilis radiata siliquoidea. All samples were taken using SCUBA.

\section{DESCRIPTION OF STUDY SITE}

Lake St. Clair lies at the center of the $125-\mathrm{km}$-long waterway between Lake Huron and Lake Erie. It has an area of $1,110 \mathrm{~km}^{2}$, a volume of $3.4 \mathrm{~km}^{3}$, and a mean depth of $3 \mathrm{~m}$. The main inflow, accounting for about $98 \%$ of the total input, is from the St. Clair River, which has a mean flow rate of about $5,100 \mathrm{~m}^{3} / \mathrm{s}$. The theoretical flushing rate of the lake is about 9 days. The waters of Lake St. Clair are usually well-mixed; thermal stratification does not occur and oxygen concentrations remain close to saturation. Other physical and chemical characteristics include: alkalinity, $81.6 \mathrm{mg} / \mathrm{L}$; total calcium, $29.1 \mathrm{mg} / \mathrm{L}$; suspended solids, $12.1 \mathrm{mg} / \mathrm{L}$; secchi depth, $1.5 \mathrm{~m}$; and chlorophyll $a, 4.7 \mu \mathrm{g} / \mathrm{L}$ (Herdendorf et al. 1986).

\section{METHODS}

Mussels were collected at 29 stations (Fig. 1) in Lake St. Clair in September, 1986. Station locations were the same as given in Pugsley et al. (1985). Divers positioned a $0.5 \mathrm{~m}^{2}$ frame on the 


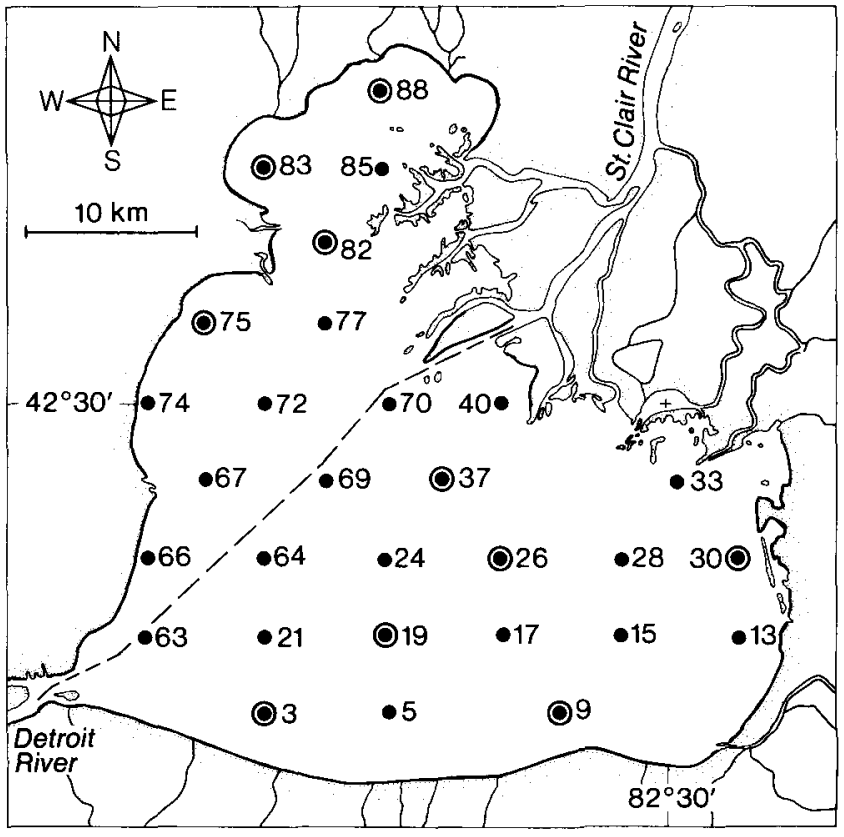

FIG. 1. Location of sampling stations in Lake St. Clair, September 1986. The circled stations were also sampled with a Ponar in October 1986. Station numbers correspond to those used by Pugsley et al. (1985). Dashed line indicates shipping channel.

lake bottom and collected all mussels, including empty shells, within the frame area. Visibility at most stations was poor, so collections were made mostly by touch, with divers probing the upper 5 $\mathrm{cm}$ of sediment. Ten replicate samples were taken at each station.

All live mussels were immediately opened and the soft tissue was placed in preweighed aluminum planchets. Dry weights of the tissue and the shell were obtained separately after drying at $60^{\circ} \mathrm{C}$ for at least $48 \mathrm{~h}$. Total shell lengths were determined to the nearest $\mathrm{mm}$ with vernier calipers.

Ages of individuals of the two most abundant species, Lampsilis radiata siliquoidea and Leptodea fragilis, were determined by counting the number of external growth rings on the shell. The annularity of the growth rings was not verified, but other investigators have confirmed that external growth rings are produced annually in environments at similar or greater latitudes (Isely 1914, Negus 1966, Haukioja and Hakala 1978, Ghent et al. 1978). Further, the slow and uniform temperature changes in large water bodies such as Lake St. Clair eliminate the primary cause of false annuli or "disturbance rings" (Grier 1922, Stansbery 1961).

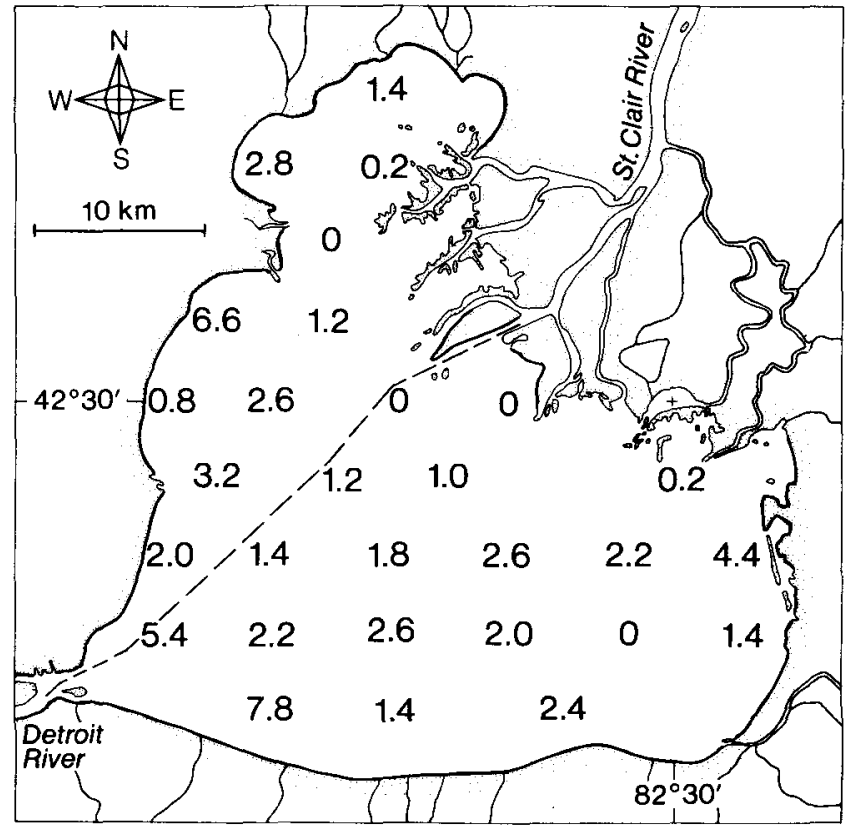

FIG. 2. Mean abundance (number per $\mathrm{m}^{2}$ ) of mussels at each of the sampling stations in Lake St. Clair.

True annuli were distinguished from false annuli using the guidelines of Stansbery (1961). When the nature of the ring was ambiguous, it was not counted as a true annulus, thus, age estimates are considered conservative.

Total annual production of $L . r$. siliquoidea was estimated from the sum of the production of each age class (Magnin and Stanczykowska 1971). Since only five individuals older than 13 years were collected and the dry weights of these individuals were not consistent with respect to age, weights used in production estimates for the $13+$ ages classes were based on the relationship $\log (\mathrm{wt})=-1.33651+$ $1.57545 \log$ (age). This relationship was derived from a regression using all individuals of this species.

\section{RESULTS}

The mean population abundance of mussels in Lake St. Clair was $2 \mathrm{~m}^{-2}$ (range $0-8 \mathrm{~m}^{2}$ ) and the mean biomass (shell-free dry weight) was $4.4 \mathrm{~g} \mathrm{~m}^{-2}$ (range $0-19.4 \mathrm{~g} \mathrm{~m}^{-2}$ ). In general, both abundance and biomass increased with increased distance downstream from the mouth of the St. Clair River (Figs. 2 and 3). This distribution was similar to trends in water column productivity and potential sources of food; both nutrients and algal pigments 


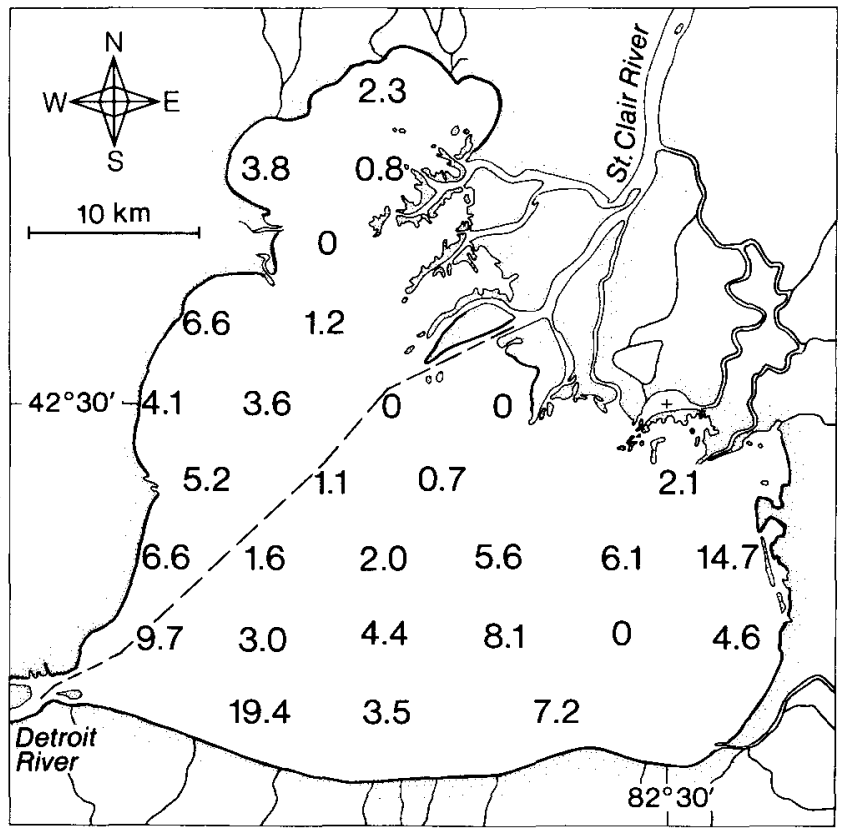

FIG. 3. Mean biomass ( $g$ shell-free dry wt per $m^{2}$ ) of mussels at each of the sampling stations in Lake St. Clair.

are lower near the mouth of the St. Clair River and increase in areas farther south (Leach 1972). Areas near the St. Clair River mouth are more influenced by the cold, low-nutrient waters from Lake Huron, while areas to the south are more influenced by the stable, enriched waters from Ontario tributaries (Leach 1980).

Substrate type at each of the 29 stations is given in Table 1. Abundances at individual stations were highest in sediments consisting of coarse sand/ gravel with some overlying silt (Stations 3, 30, and 63).

Eighteen different species were identified from the 281 individuals collected (Table 2). The three most abundant species, $L$. $r$. siliquoidea, $L$. fragilis, and Proptera alata, accounted for $45 \%, 13 \%$, and $10 \%$ of all live individuals. The former species was the most widely distributed, being collected at 22 of the 25 stations where mussels were found. Nine species were represented by less than five individuals each.

The age structures of $L$. r. siliquoidea and $L$. fragilis are given in Figure 4. Few individuals younger than 4 years of age or older than 12 years were collected for either species. For $L$. fragilis, the age-frequency distribution of individuals 4-12 years of age was quite similar to that found for mussels in other freshwater lakes (Okland 1963, Strayer et al. 1981, Paterson 1985) and reflected yearly variation in recruitment with no apparent trends in year-class strength. However, the agefrequency distribution of $L$. $r$. siliquoidea was skewed toward the older age classes; individuals 9-12 years old were far more abundant than individuals $4-8$ years old.

To determine the age at which mortality was most frequent, age determinations were also made on the empty shells (no soft tissue) of $L$. r. siliquoidea. Unlike the age-frequency distribution of live individuals, the age-frequency distribution of these dead individuals was skewed toward the younger age classes (Fig. 5).

Since young mussels are easily missed when samples are collected by hand, an additional ten replicate samples were taken with a Ponar grab at each of ten stations the following month (see Fig. 1 for the location of these stations). The samples were immediately washed through a screen with $500-\mu \mathrm{m}$ openings. Five mussels were collected in the 100 samples, and all were juveniles (either 1 or 2 years old). This compares to just three juveniles collected in the SCUBA survey. The average mussel density in the Ponar samples was $1 \mathrm{~m}^{-2}$, compared to $2.7 \mathrm{~m}^{-2}$ at the same 10 stations in the SCUBA survey.

Both shell length and dry weight of $L . r$. siliquoidea increased at a constant rate after age 4 (Fig. 6). The growth rate (expressed as increase in shell length with age) was lower than found at several sandy, shallow sites in western Lake Erie (Brown et. al. 1938), but similar to growth rates at a deep, silty site $(10 \mathrm{~m})$ in western Lake Erie (Roth and Mozley, unpublished) and at several sites in Long Point Bay, Lake Erie (McCuaig and Green 1983). Absolute growth rate in mussels is related to substrate type, with most rapid growth occurring in coarse sediment and slower growth occurring in fine sediments (Stansbery 1970, Hinch et. al. 1986). This is more related to a morphological adaptation to the environment than to differences in food or feeding efficiency; mussels with large and long shells are more suited to maintaining position in sandy sediments, while mussels with smaller, more obese shells are less likely to sink in soft sediments (Tevesz and McCall 1979, Hinch et. al. 1986). Consistent with these results, length at a given age in this survey was generally greater for individuals collected from stations with coarse sediments than from stations with fine sediments (Table 3). 
TABLE 1. Water depth and substrate type of sampling stations in Lake St. Clair, September 1986.

\begin{tabular}{cclccl}
\hline \hline Station & $\begin{array}{c}\text { Depth } \\
(\mathrm{m})\end{array}$ & \multicolumn{1}{c}{ Substrate } & Station & $\begin{array}{c}\text { Depth } \\
(\mathrm{m})\end{array}$ & \multicolumn{1}{c}{ Substrate } \\
\hline 85 & 3.3 & silty clay & 28 & 6.1 & silty clay \\
74 & 3.0 & silty sand & 63 & 6.1 & silt over gravel \\
83 & 3.6 & silt, macrophytes & 70 & 6.1 & sand \\
33 & 3.6 & sand & 21 & 6.4 & silt \\
82 & 4.2 & sand & 72 & 6.4 & silt \\
40 & 4.5 & sand & 17 & 6.7 & silt \\
66 & 4.5 & silty sand & 64 & 6.7 & silt \\
88 & 4.5 & silt, macrophytes & 67 & 6.7 & silt \\
13 & 4.8 & silt & 69 & 6.7 & silt \\
30 & 4.8 & silt over coarse sand & 15 & 7.0 & silt \\
75 & 4.8 & silt & 37 & 7.0 & silty clay \\
3 & 5.2 & silt over gravel & 19 & 7.3 & silt \\
77 & 5.2 & sand & 24 & 7.3 & silt \\
9 & 5.5 & coarse sand, gravel & 26 & 7.3 & silt \\
5 & 6.1 & silt & & & \\
\hline
\end{tabular}

TABLE 2. List and frequency (total collected) of unionid species in Lake St. Clair, September 1986.

\begin{tabular}{|c|c|}
\hline Species & $\begin{array}{c}\text { Total } \\
\text { Collected }\end{array}$ \\
\hline Amblema plicata Say & 6 \\
\hline Anodonta grandis grandis Say & 14 \\
\hline Elliptio dilatata (Rafinesque) & 20 \\
\hline Fusconaia flava (Rafinesque) & 10 \\
\hline Lampsilis fasciola Rafinesque & 1 \\
\hline Lampsilis ventricosa (Barnes) & 16 \\
\hline \multicolumn{2}{|l|}{ Lampsilis radiata siliquoidea } \\
\hline (Barnes) & 127 \\
\hline Lasmigona complanata (Barnes) & 1 \\
\hline Leptodea fragilis (Rafinesque) & 37 \\
\hline Ligumia nasuta (Say) & 8 \\
\hline Ligumia recta (Lamarck) & 3 \\
\hline Obvaria subrotunda (Rafinesque) & 1 \\
\hline \multicolumn{2}{|l|}{ Pleurobema cordatum $f$. coccineum } \\
\hline (Rafinesque) & 1 \\
\hline Proptera alata (Say) & 29 \\
\hline Quadrula quadrula (Rafinesque) & 2 \\
\hline Strophitus undulatus (Say) & 1 \\
\hline Truncilla donaciformis (Lea) & 1 \\
\hline Truncilla truncata Rafinesque & 3 \\
\hline
\end{tabular}

Annual production of $L . r$. siliquoidea over all stations was $0.20 \mathrm{~g} \mathrm{DW} \mathrm{m}^{-2} \mathrm{y}^{-1}$ and the turnover ratio $(\mathrm{P} / \mathrm{B})$ was 0.13 .

\section{DISCUSSION}

Mussel abundances in this survey were generally lower than abundances reported in other surveys in the Great Lakes. For instance, mean abundances of $5 \mathrm{~m}^{-2}$ (Carr and Hiltunen 1965; Peterson grab), $7 \mathrm{~m}^{-2}$ (Wood 1963; drag dredge) and $10 \mathrm{~m}^{-2}$ (McCall et al. 1979; SCUBA) have been reported from western Lake Erie, while a mean abundance of $7 \mathrm{~m}^{-2}$ was reported from seven stations in southwestern Lake St. Clair (University of Windsor 1984; SCUBA). Our results can be directly compared to the latter survey (conducted in 1983) since three sampling stations overlapped and collection techniques were similar (SCUBA). Abundances in our survey were significantly $(P<0.05)$ lower at two of the three stations (Table 4). Since only three stations were compared, it is not clear whether our lower abundances reflected an actual decline in the population, or were simply a result of horizontal patchiness. Yet reports of a large die-off of mussels in Lake St. Clair in the summer of 1985 (Neves 1987; David Kenaga, Michigan Department of Natural Resources, personal communication 1988) may indicate that a large decline in populations in the time period between the two surveys did indeed occur.

In western Lake Erie, mussel abundance and 

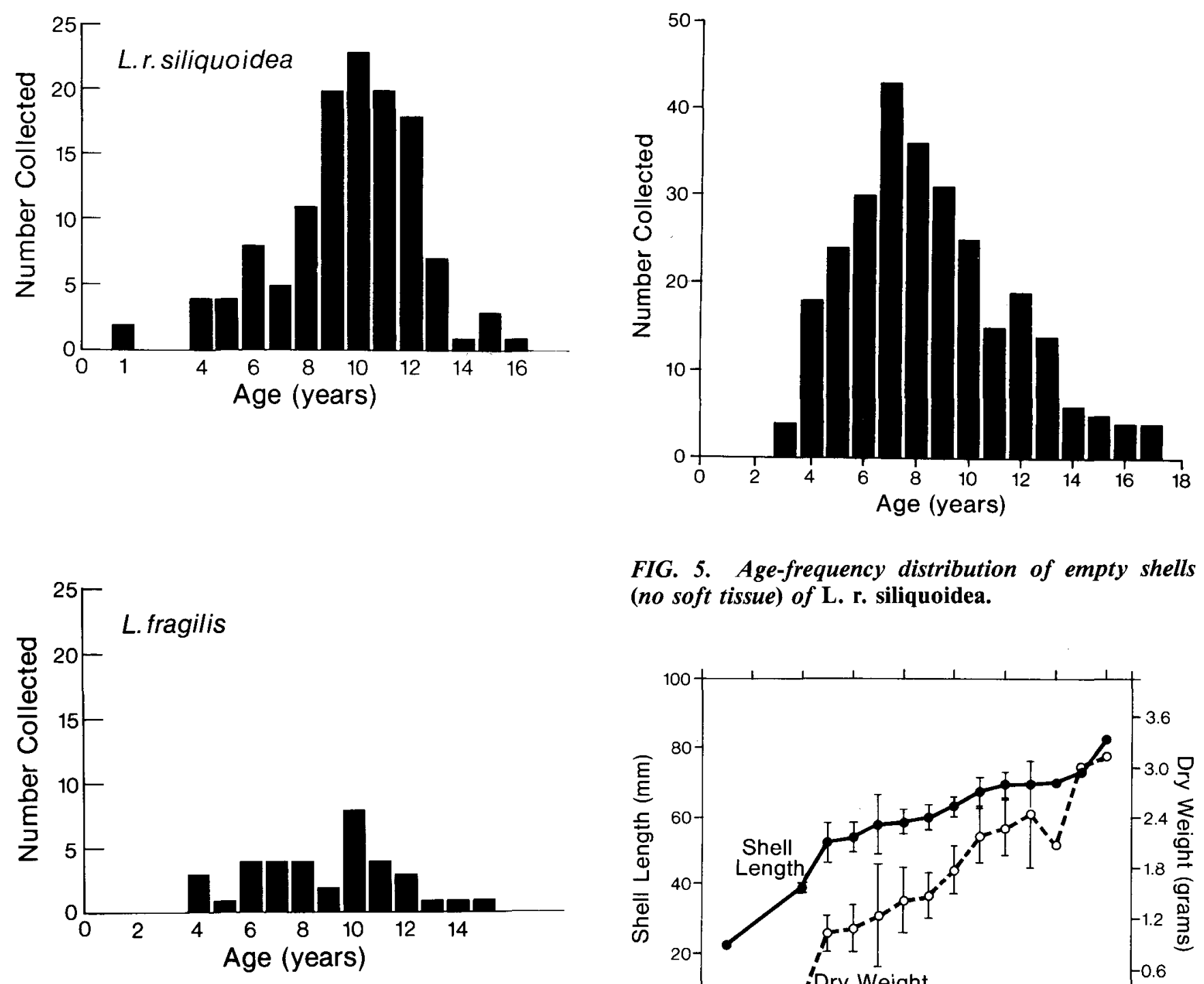

FIG. 4. Age-frequency distribution of the two most abundant species, L. r. siliquoidea and $\mathrm{L}$. fragilis.

diversity have apparently declined over the past few decades (Mackie et al. 1980). Unfortunately, historical records of mussel abundance in Lake St. Clair are lacking. Almost a century ago, Reighard (1894) reported finding 20 species in the lake, with L. r. siliquoidea being very "widespread and abundant" and Proptera alata, Ligumia nasuta, and Anodonta grandis being found "frequently." Thus, mussel diversity and composition appear to have changed little since the turn of the century. The only notable difference between our survey and Reighard's was in the relative abundance of $L$. fragilis; Reighard reported this species as "scarce,"

FIG. 5. Age-frequency distribution of empty shells (no soft tissue) of L. r. siliquoidea.

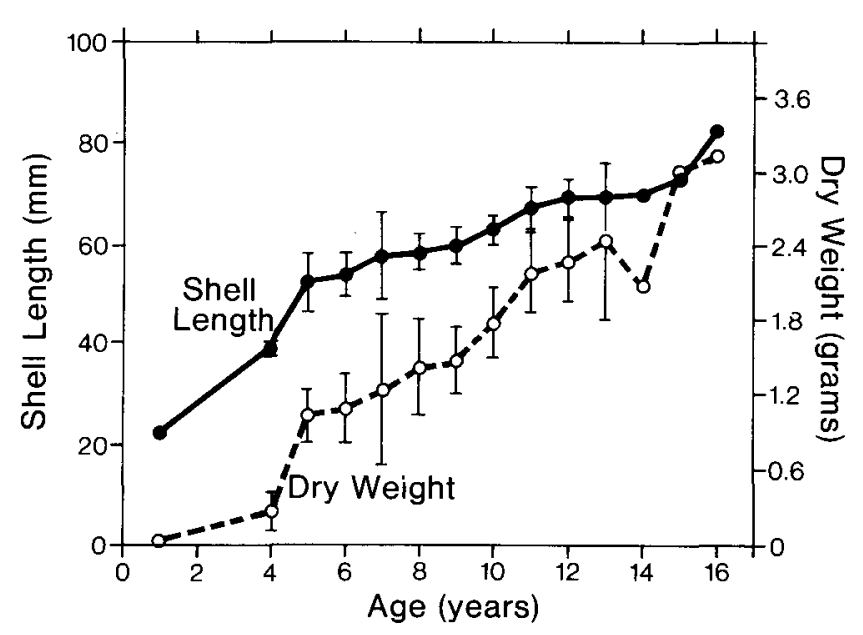

FIG. 6. Mean shell length $v$ s. age $( \pm 95 \%$ confidence level) and mean dry weight vs. age ( $\pm 95 \%$ confidence level) of L. r. siliquoidea in Lake St. Clair, September 1986.

whereas it was the second most abundant species in our survey.

The scarcity of individuals younger than 4 years is a common finding in population surveys of mussels (Lewandowski and Stanczykowska 1975, Negus 1966, Green 1980, Strayer et al. 1981, Samad and Stanley 1986). Because of their small size, juvenile mussels are easily missed when sam- 
TABLE 3. Mean shell length ( $\mathrm{mm}$ ) of L. r. siliquoidea at a given age at stations with sand/gravel sediments (total of 11 stations) and at stations with silt sediments (total of 18 stations) in Lake St. Clair. $S D=$ standard deviation, $n=$ number of individuals.

\begin{tabular}{ccccccrrr}
\hline \hline & \multicolumn{3}{c}{ Sand/Gravel } & & \multicolumn{3}{c}{ Silt } \\
\cline { 2 - 6 } Age & $\mathrm{x}$ & SD & $\mathrm{n}$ & & $\mathrm{x}$ & $\mathrm{SD}$ & $\mathrm{n}$ \\
\hline 5 & 51.8 & 6.2 & 2 & & 51.9 & 1.8 & 2 \\
6 & 56.5 & 5.1 & 3 & & 52.0 & 4.4 & 5 \\
7 & 59.5 & 0.7 & 2 & & 56.4 & 10.2 & 3 \\
8 & 60.2 & 4.2 & 2 & & 58.4 & 5.3 & 9 \\
9 & 65.4 & 6.1 & 7 & & 56.1 & 5.8 & 13 \\
10 & 69.7 & 4.8 & 2 & & 62.8 & 6.0 & 21 \\
11 & 67.3 & 5.5 & 6 & & 67.9 & 9.6 & 14 \\
12 & 73.6 & 8.1 & 5 & & 68.0 & 7.0 & 13 \\
13 & 73.2 & 14.1 & 2 & & 69.3 & 4.7 & 5 \\
\hline
\end{tabular}

TABLE 4. Comparison of mean mussel abundances (per $\mathrm{m}^{-2}$ ) at three stations in Lake St. Clair in 1983 (University of Windsor 1984) and in 1986 (this study). Standard error in parentheses. ${ }^{*}=$ Abundances significantly different at the 0.05 level (t-test).

\begin{tabular}{ccc}
\hline \hline Station & 1983 & 1986 \\
\hline 3 & $13.8(1.7)$ & $7.8(1.5)^{*}$ \\
21 & $9.8(2.1)$ & $2.2(0.9)^{*}$ \\
66 & $2.4(0.6)$ & $2.0(0.7)$ \\
\hline
\end{tabular}

ples are collected by hand, and they apparently burrow deeper into the sediments than do adults (Coker et al. 1921), further confounding the sampling problem. Using a grab sampler might provide a better representative number of juveniles in the population (Paterson 1985), but total numbers are likely to be underestimated (Haukioja and Hakala 1974). Our study showed, as is typical, that more juveniles are collected when using a grab sampler, but total abundance is better estimated using SCUBA.

The age-frequency distribution of $L . r$. siliquoidea indicated a population dominated by individuals $9-12$ years old. The decline in the number of individuals $12+$ years old and the near absence of individuals $<4$ years old was likely related to age-specific natural mortality, and biased sampling techniques, respectively. However, the relatively low number of 4- to 8-year-old individuals is not easily explained. Reasons may include the following: (1) a decline in recruitment success of $L . r$. siliquoidea since 1978 (year class of 8-year-olds); (2) an increase in mortality of young individuals since 1978; (3) recruitment since 1978 was typical, while recruitment between 1974 and 1977 (year classes of 9-12 year olds) was exceptionally high.

Annual recruitment success of mussels is highly variable and depends on environmental conditions during the breeding period (Tudorancea 1972) and on the availability of fish hosts for the glochidia. In large water bodies like Lake St. Clair, conditions are relatively stable on an annual basis and, although events affecting recruitment (high or low water levels, high spring runoff, fish distributions, etc.) can vary from year to year, environmental conditions that could have consistently impaired recruitment in Lake St. Clair since 1978 are not immediately apparent. Populations of fish species which serve as hosts for the glochidia of $L$. r. siliquoidea (e.g., yellow perch, smallmouth bass, largemouth bass, bluegill, and crappie among others; Clarke 1981) have remained stable or increased over the past decade (Robert Haas, Michigan Department of Natural Resources, personal communication, 1987). An increase in mortality of individuals 8 years of age or less in recent years could account for the low abundances. The die-off of mussels noted in 1985 may have consisted mostly of individuals in this age category. This seems plausible particularly since these younger age classes were more frequent in the agefrequency distributions of dead individuals (empty shells) than of live individuals (compare Fig. 4 to Fig. 5). Under normal population demographic patterns, older individuals should constitute the majority of dead specimens. Unfortunately, aging empty shells only identifies the age at which death occurred and not the year of death. The condition of the empty shells, in terms of deterioration state, was not recorded.

The biomass of mussels in Lake St. Clair was generally similar to biomass estimates from other freshwater lakes (Table 5). However, because of the dominance of older individuals in the population, the annual turnover ratio of $L$. r. siliquoidea was only 0.13 , which is lower than found in these other areas. The mean biomass of $4.4 \mathrm{~g} \mathrm{~m}^{-2}$ was about four times greater than the mean biomass of all other benthic macroinvertebrates occurring in the lake (Hudson et al. 1986).

Since few young individuals of the dominant species, L. r. siliquoidea, are now present in the population, mussel numbers may decrease dramatically in the next 5 years when the current large 
TABLE 5. Biomass ( $g$ shell-free dry $w t \mathrm{~m}^{-2}$ ) and turnover ratio (production/biomass) of Unionidae from various lentic environments. Modified from Strayer et al. (1981) and Paterson (1985).

\begin{tabular}{|c|c|c|c|}
\hline Water Body & Biomass & $\mathrm{P} / \mathrm{B}$ & Reference \\
\hline $\begin{array}{l}\text { Lake Zbechy } \\
\text { Total Unionidae }\end{array}$ & 3.17 & 0.45 & Kasprzak (1986) \\
\hline $\begin{array}{l}\text { Mikolajskie Lake } \\
\text { Total Unionidae }\end{array}$ & 0.26 & 0.34 & $\begin{array}{l}\text { Lewandowski and } \\
\text { Stanczykowska (1975) }\end{array}$ \\
\hline $\begin{array}{l}\text { Lac des Deux Montagnes } \\
\text { Total Unionidae } \\
\text { Lampsilis radiata }\end{array}$ & $\begin{array}{l}8.60 \\
0.13\end{array}$ & $\begin{array}{l}0.20 \\
0.32\end{array}$ & $\begin{array}{l}\text { Magnin and } \\
\text { Stanczykowska (1971) }\end{array}$ \\
\hline $\begin{array}{l}\text { Lac Saint Louis } \\
\text { Total Unionidae } \\
\text { Lampsilis radiata }\end{array}$ & $\begin{array}{l}0.71 \\
0.10\end{array}$ & $\begin{array}{l}0.10 \\
0.19\end{array}$ & $\begin{array}{l}\text { Magnin and } \\
\text { Stanczykowska (1971) }\end{array}$ \\
\hline $\begin{array}{l}\text { Morice Lake } \\
\quad \text { Elliptio complanata }\end{array}$ & 8.04 & 0.19 & Paterson (1985) \\
\hline $\begin{array}{l}\text { Lake St. Clair } \\
\text { Total Unionidae } \\
\text { Lampsilis } r . \\
\text { siliquoidea }\end{array}$ & $\begin{array}{l}4.40 \\
1.54\end{array}$ & 0.13 & This Study \\
\hline $\begin{array}{l}\text { Mirror Lake } \\
\quad \text { Total Unionidae }\end{array}$ & 0.05 & 0.006 & Strayer et al. (1981) \\
\hline
\end{tabular}

number of $9-12$ year olds declines as a result of natural age-specific mortality. Future surveys of mussel abundances, along with an examination of the age frequency distribution of $L$. r. silquoidea, should provide some valuable insights into the changing nature of the mussel population in Lake St. Clair.

\section{ACKNOWLEDGMENTS}

We thank M. Duquet of the R/V Bluewater for his outstanding support during field operations, $T$. Heatlie and $\mathbf{J}$. Allen for their dedication and perseverance during sample collection, M. Lansing for help in processing the data, C. Pugsley for providing the University of Windsor survey data, R. Hoeh and T. Freitag for help in identifying the more difficult specimens, J. Roth for generously providing unpublished material, W. Gardner, M. Quigley, and A. Beeton for their insightful comments on the manuscript, and R. Dermott and J. Metcalfe for suggestions during the review process. GLERL Contribution No. 587.

\section{REFERENCES}

Brown, C. J. D., Clark, C., and Gleissner, B. 1938. The size of certain naiades from western Lake Erie in relation to shoal exposure. Amer. Midl. Nat. 19:682-701.

Carr, J. F., and Hiltunen, J. K. 1965. Changes in the bottom fauna of western Lake Erie from 1930 to 1961. Limnol. Oceanogr. 10:551-569.

Clarke, A. H. 1981. The Freshwater Molluscs of Canada. Ottawa: National Museums of Canada.

Coker, R. E., Shira, A. F., Clark, M. W., and Howard, A. D. 1921. Natural history and propagation of fresh-water mussels. Bull. U.S. Bur. Fish. 37:79-181.

Ghent, A. W., Singer, R., and Johnson-Singer, L. 1978. Depth distributions determined with SCUBA, and associated studies of the freshwater unionid clams Elliptio complanata and Anodonta grandis in Lake Bernard, Ontario. Can. J. Zool. 56:1654-1663.

Gooderich, C., and van der Schalie, H. 1932. The naiad species of the Great Lakes. Occ. Papers Mus. Zool., University Michigan 238:8-14.

Green, R. H. 1980. Role of a unionid clam population in the calcium budget of a small arctic lake. Can. $J$. Fish. Aquat. Sci. 37:219-224. 
Grier, N. M. 1922. Observations on the rate of growth of the shell of lake dwelling mussels. Amer. Midl. Nat. 8:129-148.

Haukioja, E., and Hakala, T. 1974. Vertical distribution of freshwater mussels (Pelecypoda, Unionidae) in southwestern Finland. Ann. Zool. Fennici. 11:127-130.

, and Hakala, T. 1978. Measuring growth from shell rings in populations of Anodonta piscinalis (Pelecypoda, Unionidae). Ann. Zool. Fennici 15:60-65.

Herdendorf, C. E., Raphael, C. N., and Jaworski, E. 1986. The ecology of Lake St. Clair wetlands: a community profile. U.S. Fish Wildl. Serv. Biol. Rep. 85(7.7), Washington, D.C.

Hinch, S. C., Bailey, R. C., and Green R. H. 1986. Growth of Lampsilis radiata (Bivalvia: Unionidae) in sand and mud: a reciprocal transplant experiment. Can. J. Fish. Aquat. Sci. 43:548-552.

Hudson, P. L., Davis, B. C., Nichols, S. J., and Tomcko, C. M. 1986. Environmental studies of macrozoobenthos, aquatic macrophytes, and juvenile fishes in the St. Clair-Detroit river system, 1983-1984. Administrative report no. 86-7, USFWSNFC-GL/AR-86-7, Ann Arbor, MI.

Isely, F. B. 1914. Experimental study on the growth and migration of freshwater mussels. U.S. Bureau of Fisheries Document 7922, Washington, D.C.

Isom, B. G., and Gooch, C. 1986. Rationale and sampling designs for freshwater mussels Unionidae in streams, large rivers, impoundments, and lakes. In Rationale for sampling and interpretation of ecological data in the assessment of freshwater systems. ed. B. G. Isom, pp. 46-59. Philadelphia, PA: ASTM STP, American Society for Testing and Materials.

Kasprzak, K. 1986. Role of Unionidae and Sphaeriidae (Mollusca, Bivalvia) in the eutrophic Lake Zbechy and its outflow. 1986. Int. Revue ges. Hydrobiol. 71:315-334.

Leach, J. H. 1972. Distribution of chlorophyll $a$ and related variables and Ontario waters of Lake St. Clair. In Proceedings 15th Conf. Great Lakes Res., pp. 80-86. Internat. Assoc. Great Lakes Res.

1980. Limnological sampling intensity in

Lake St. Clair in relation to distribution of water masses. J. Great Lakes Res. 6:141-145.

Lewandowski, K., and Stanczykowska, A. 1975. The occurrence and role of bivalves of the family Unionidae in Miklajskie Lake. Ekol. Pol. 23:317-334.

Mackie, G. L., White, D. S., and Zdeba, T. W. 1980. A guide to freshwater mollusks of the Laurentian Great Lakes with special emphasis on the genus Pisidium. U.S. Environmental Protection Agency, EPA-600/380-068.

Magnin, E., and Stanczykowska, A. 1971. Quelques donnees sur la croissance, la biomass et la production annuelle de trois mollusques unionidae de la region de Montreal. Can. J. Zool. 49:491-497.

McCall, P. L., Tevesz, M. J. S., and Schwelgien, S. F. 1979. Sediment mixing by Lampsilis radiata siliquoidea (Mollusca) from western Lake Erie. J. Great Lakes Res. 5:105-111.

McCuaig, J. M., and Green, R. H. 1983. Unionid growth curves derived from annual rings: a baseline model for Long Point Say, Lake Erie. Can. J. Fish. Aquat. Sci. 40:436-442.

Negus, C. L. 1966. A quantitative study of growth and production of unionid mussels in the river Thames at Reading. J. Anim. Ecol. 35:513-532.

Neves, R. J. 1987. Recent die-offs of freshwater mussels in the United States: an overview. In Proceedings of the workshop on die-offs of freshwater mussels in the United States. ed. R. J. Neves, pp. 7-18. U.S. Fish and Wildlife Service, Upper Mississippi River Conservation Committee.

Okland, J. 1963. Notes on population density, age distribution, growth, and habitat of Anodonta piscinalis Nilss. (Moll., Lamellibr.) in a Norwegian lake. Nytt. Mag. Zool. 11:19-43.

Paterson, C. G. 1985. Biomass and production of the unionid, Elliptio complanata (Lightfoot) in an old reservoir in New Brunswick, Canada. Freshwat. Invert. Biol. 4:201-207.

Pugsley, C. W., Hebert, P. D. N., Wood, G. W., Brotea, G., and Obal, T. W. 1985. Distribution of contaminants in clams and sediments from the HuronErie corridor. I-PCB's and octachlorostyrene. $J$. Great Lakes Res. 11:275-289.

Reighard, J. E. 1894. A biological examination of Lake St. Clair. Bull. Mich. Fish Comm. No. 4, Lansing, MI.

Samad, F., and Stanley, J. G. 1986. Loss of freshwater shell fish after water drawdown in Lake Sebasticook, Maine. J. Freshwat. Biol. 3:519-523.

Stansbery, D. H. 1961. The naiades (Mollusca, Pelecypoda, Unionacea) of Fishery Bay, South Bass Island, Lake Erie. Part I. Introduction history, faunal origins, and physiography. Sterkiana 5:1-37.

1970. A study of the growth rate and longevity of the naiad Amblema plicata (Say, 1817) in Lake Erie (Bivalvia: Unionidae). Am. Malacol. Union Inc. Bull. 37:78-79.

Strayer, D. L., Cole, J. J., and Likens, G. E. 1981. Biomass and annual production of the freshwater mussel Elliptio complanata in an oligotrophic softwater lake. Freshwater. Biol. 11:435-440.

Tevesz, M. J. S., and McCall, P. L. 1979. Evolution of substratum preference in bivalves (Mollusca). $J$. Paleontol. 53:112-120.

Tudorancea, C. 1972. Studies on Unionidae populations from the Crapina-Jijila complex of pools (Danube zone liable to inundation). Hydrobiologia 39:527-561. 
University of Windsor. 1984. Annual report UP-175. A case study of selected toxic contaminants in the Essex Region. Great Lakes Institute, University of Windsor, Windsor, Ontario.

van der Schalie, H. 1961. The naiad (freshwater mussel) fauna of the Great Lakes. In Univ. Michigan Great Lakes Res. Div. Publ. No. 7, pp. 156-157. Ann Arbor, Michigan.
1986. Mussels in the Detroit River opposite Cobo Hall. Mich. Acad. 18:31-34.

Wood, K. G. 1963. The bottom fauna of western Lake Erie, 1951-1952. In Univ. Michigan Great Lakes Res. Div. Publ. No. 10, pp. 258-265. Ann Arbor, Michigan. 